\title{
MINAT BELAJAR SISWA PADA MATA PELAJARAN MATEMATIKA KELAS IV SD NEGERI KARANGROTO 04 SEMARANG
}

\author{
Siti Hidayatus Sholehah ${ }^{1}$, Diana Endah Handayani ${ }^{2}$, Singgih Adhi Prasetyo ${ }^{3}$ \\ Pendidikan Guru Sekolah Dasar (PGSD), FIP, Universitas PGRI Semarang \\ Email: hidayatussholehah20@gmail.com
}

\begin{abstract}
Abstrak
Tujuan penelitian ini adalah untuk mendeskripsikan minat belajar siswa kelas IV pada mata pelajaran matematika SD Negeri Karangroto 04 Semarang. Jenis penelitian ini adalah deskriptif kualitatif. Subyek dalam penelitian ini adalah seluruh siswa kelas IV yang berjumlah 46 siswa. Metode yang digunakan dalam penelitian mengenai minat belajar matematika pada proses pembelajaran dengan cara pengumpulan data melalui koesioner (angket), wawancara dari guru dan siswa, observasi dan dokumentasi. Hasil penelitian ini terbukti bahwa minat belajar siswa kelas IV pada mata pelajaran matematika di SD Negeri Karangroto 04 Semarang menunjukan hasil sebesar $79,3 \%$ tergolong kriteria minat belajar Sangat Tinggi.
\end{abstract}

Kata kunci : Minat Belajar, Matematika.

\begin{abstract}
The purpose of this study was to describe the learning interest of fourth grade students in mathematics subjects at SD Negeri Karangroto 04 Semarang. This type of research is qualitative descriptive. The subjects in this study were all fourth grade students totaling 46 students. The method used in the study of the interest in learning mathematics in the learning process by means of collecting data through questionnaires (questionnaires), interviews from teachers and students, observation and documentation. The results of this study proved that the interest in learning fourth grade students in mathematics subjects at Karangroto 04 Elementary School Semarang showed results of $79.3 \%$ classified as Very High interest in learning criteria.
\end{abstract}

Keywords: Learning Interest, Mathematics.

\section{Pendahuluan}

Matematika merupakan salah satu disiplin ilmu yang dapat meningkatkan kemampuan berpikir dan berargumentasi, memberikan kontribusi dalam penyelesaian masalah sehari-hari dan dalam dunia kerja, serta memberikan dukungan dalam perkembangan ilmu pengetahuan dan teknologi. Dalam proses pembelajaran, matematika dapat mengembangkan kreativitas berpikir siswa yang dapat meningkatkan kemampuan berpikir siswa (Susanto, 2014:185).

Mata pelajaran matematika diberikan pada semua peserta didik mulai dari sekolah dasar untuk membekali peserta didik dengan kemampuan berpikir logis, analitis, sistematis, kritis, dan kreatif, serta kemampuan bekerjasama. Kompetensi tersebut diperlukan agar peserta didik dapat memiliki kemampuan memperoleh, mengelola, dan memanfaatkan informasi untuk bertahan hidup pada keadaan yang selalu berubah, tidak pasti, dan kompetitif.

Menurut Cornelus (dalam Abdurrahman 1999:253) mengatakan bahwa ada banyak alasan tentang perlunya siswa belajar matematika, yaitu: (1) merupakan sarana berpikir yang jelas dan logis, (2) sarana memecahkan masalah kehidupan sehari-hari, (3) sarana mengenal pola pola hubungan dan generalisasi pengalaman, (4) sarana untuk mengembangkan kreativitas, dan (5) sarana untuk meningkatkan kesadaran terhadap perkembangan budaya. 
Susanto (2014:191) menjelaskan bahwa pembelajaran matematika perlu mendapat perhatian dan penanganan serius. Hal ini penting, sebab hasil-hasil penelitian masih menunjukkan bahwa proses pembelajaran matematika di sekolah dasar masih belum menunjukkan hasil yang memuaskan. Rendahnya prestasi belajar matematika siswa tentu disebabkan oleh banyak faktor, misalnya masalah klasik tentang penerapan metode pembelajaran yang masih terpusat pada guru (teacher oriented) dan guru yang masih belum mengoptimalkan interaksi untuk menumbuhkembangkan minat belajar serta kemampuan berpikir dalam diri siswa, sehingga siswa belum mampu berpartisipasi secara aktif dalam mengikuti pembelajaran.

Menurut Susanto (2014:66-67) minat merupakan faktor yang berpengaruh secara signifikan terhadap keberhasilan belajar. Pernyataan ini didukung oleh pendapat Hartono (dalam Susanto, 2014:67) yang menyatakan bahwa minat memberikan sumbangan besar terhadap keberhasilan belajar peserta didik. Prestasi belajar matematika yang baik tidak akan tercapai secara maksimal apabila siswa tidak memiliki minat belajar. Minat mempunyai peranan yang penting dalam proses belajar mengajar untuk meningkatkan prestasi belajar.

Selain itu, hasil riset Trends in International Mathematics and Science Study (TIMSS) pada 2015 mengkonfirmasi rendahnya penguasaan Matematika pelajar Indonesia. Negara berpenduduk lebih dari 250 juta orang ini hanya berada di peringkat ke- 45 dari 50 negara yang disurvei.

Dalam dunia pendidikan di sekolah, minat memegang peranan penting dalam belajar. Karena minat ini merupakan kekuatan motivasi yang menyebabkan seseorang memusatkan perhatian terhadap seseorang, suatu benda, atau kegiatan tertentu. Dengan demikian, minat merupakan unsur yang menggerakkan motivasi seseorang sehingga orang tersebut dapat berkosentrasi terhadap suatu benda atau kegiatan tertentu.

Islamuddin (2012:187) minat (interest) berarti kecenderungan dan kegairahan yang tinggi atau keinginan yang besar terhadap sesuatu. Suatu minat dapat diekspresikan melalui suatu pernyataan yang menunjukkan bahwa siswa lebih menyukai suatu hal dari pada hal lainnya, dapat pula dimanifestasikan melalui partisipasi dalam suatu aktivitas. Siswa yang memiliki minat terhadap subyek tertentu cenderung untuk memberikan perhatian yang lebih besar terhadap subyek tersebut.

Slameto (2010:180) minat merupakan suatu rasa lebih suka dan rasa ketertarikan pada suatu hal atau aktivitas tanpa ada yang menyuruh. . Kegiatan yang diminati seseorang akan diperhatikan terus-menerus yang disertai dengan rasa senang hati. Minat adalah kecenderungan yang tetap untuk memperhatikan dan mengenang beberapa kegiatan. Minat sangat besar pengaruhnya terhadap belajar. Aktivitas belajar tanpa didukung oleh minat cenderung tidak diikuti dengan sungguh-sungguh atau sepenuh hati.

Bagi peserta didik yang memiliki minat terhadap suatu pelajaran akan mempelajari pelajaran tersebut dengan sungguh-sungguh, karena ada daya tarik baginya. Menurut Syah (2006:151) minat berarti kecenderungan atau kegairahan yang tinggi atau keinginan yang besar terhadap sesuatu. Proses belajar akan berjalan dengan lancar bila disertai dengan minat. Peserta didik yang mempunyai minat pada suatu pelajaran berarti ia telah menetapkan tujuan yang berguna sehingga akan cenderung untuk menyukainya.

Siswa yang kurang berminat terhadap pendidikan, biasanya akan menunjukkan prestasi di bawah kemampuannnya pada semua mata pelajaran atau pada mata pelajaran yang tidak diminatinya. Peserta didik akan terkesan pasif atau malas untuk mengikuti pelajaran tersebut. Oleh sebab itu, diharapkan para siswa memiliki minat yang tinggi khususnya pelajaran matematika karena matematika merupakan sarana berfikir yang jelas dan logis, sarana untuk memecahkan masalah kehidupan sehari-hari, dan sarana untuk mengembangkan kreativitas.

Berdasarkan uraian yang telah dijabarkan di atas, maka dapat dimengerti bahwa minat memiliki peran langsung yang penting, terutama dalam pelajaran matematika. Minat akan membuat siswa merasa lebih ringan dalam mengerjakan tugas-tugas yang diberikan kepadanya, dapat berkonsentrasi dan pelajaran matematika yang sukar mungkin menjadi mudah baginya. Dalam hal ini peneliti ingin mencari tahu tentang gambaran minat terhadap 
mata pelajaran matematika pada siswa. Tujuan penelitian ini adalah untuk mendeskripsikan minat belajar siswa kelas IV pada mata pelajaran matematika SD Negeri Karangroto 04 Semarang.

\section{Metode}

Penelitian ini dilakukan adalah jenis kualitatif deskriptif. Menurut Moleong (2014:6) mendeskripsikan bahan penelitian kualitatif adalah penelitian yang bermaksud untuk memahami fenomena tentang apa yang dialami oleh subyek penelitian, misalnya perilaku, persepsi, tindakan, dan lain-lain, secara menyeluruh, dan dengan cara deskripsi dalam kata bahasa, pada suatu konteks khusus yang alamiah dan dengan memanfaatkan berbagai metode ilmiah. Peneliti melihat secara langsung bagaimana minat belajar siswa yang ada didalam kelas ketika proses pembelajaran matematika yang berlangsung di kelas IV SD Negeri Karangroto 04 Semarang.

Rancangan kegiatan penelitian ini mengikuti tahapan penelitian deskriptif kualitatif secara umum. Terdapat tiga tahapan meliputi tahap persiapan, tahap pelaksanaan dilapangan, dan tahap pasca lapangan. Pada tahap persiapan dilakukan yaitu, membuat rancangan penelitian, menetapkan lokasi penelitian, mengurus Izin, melaksanakan observasi awal, memilih dan menetapkan informan, menyiapkan instrumen penelitian, mempersiapkan diri sebagai peneliti. Pada tahap lapangan ini, dilakukan pengumpulan data menggunakan instrumen yang telah disiapkan sebelumnya. Pada tahap pasca lapangan kegiatan yang dilakukan yaitu menganalisis data yang diperoleh dari lapangan. Analisis data tersebut dilakukan secara deskriptif sesuai dengan data yang terkumpul dari instrumen yang digunakan. Data yang diperoleh dari obeservasi awal sampai akhir penelitian dianalisis, sehingga diperoleh suatu kesimpulan.

Sumber data pada penelitian ini diperoleh dari hasil angket (koesioner), wawancara, observasi dan dokumentasi yang dilakukan di SD Negeri Karangroto 04 Semarang. Informan penelitian ini adalah guru dan siswa.

Teknik pengumpulan data yang digunakan peneliti yaitu angket respon siswa. observasi, wawancara dan dokumentasi. Angket yang digunakan dalam penelitian ini adalah angket tentang minat belajar matematika yang berbentuk tertutup/ terstruktur, yaitu siswa menjawab sejumlah pernyataan yang menggambarkan hal-hal yang ingin diungkap disertai alternative jawaban. Kemudian siswa diminta merespon setiap pernyataan sesuai dengan keadaan diri yang diketahui dengan cara membubuhkan tanda centang $(\sqrt{ })$ pada alternative jawaban yang tersedia. Teknik pengumpulan data yang kedua adalah observasi. Dalam mengobservasi, peneliti menggunakan lembar observasi yang berisi indikator tentang minat belajar matematika, mengamati siswa pada proses pembelajaran matematika dan mengisi lembar observasi yang sesuai dengan kondisi yang ada di lapangan. Teknik pengumpulan data yang ketiga adalah wawancara. Pada penelitian ini, peneliti menggunakan jenis wawancara semi terstruktur. Dalam melakukan wawancara peneliti sudah menyiapkan intrumen penelitian berupa pertanyaan-pertanyaan yang nantinya akan dijawab responden. Wawancara ditujukan kepada siswa dan guru yang mengajar mata pelajaran matematika. Wawancara ini dilakukan untuk memperoleh data tentang minat siswa dan pengalaman guru dalam mengajar kelas IV. Teknik pengumpulan data yang terakhir adalah dokumentasi. Dokumentasi dalam penelitian ini berisi dokumen berupa foto-foto proses pembelajaran matematika. Dokumentasi bertujuan agar pada saat pembelajaran berlangsung peneliti dapat melihat dan mendokumentasikan aktivitas siswa secara nyata.

Teknik analisis data dilakukan dengan tiga tahap yaitu analisis sebelum lapangan, analisis selama di lapangan yang terdiri dari reduksi data, penyajian data, dan vertifikasi data, serta analisis setelah pengumpulan data terakhir dengan cara data yang telah diperoleh selama masa pengumpulan data kemudian dianalisis dari awal hingga akhir untuk penyusunan laporan sehingga diperoleh kesimpulan akhir. Secara khusus, data yang terkumpul dicari ratarata dan dianalisis secara deskriptif kualitatif. 


\section{Hasil dan Pembahasan}

Data hasil Minat Belajar Siswa dalam proses pembelajaran matematika diperoleh dari kuesioner yang terdiri dari 4 indikator minat belajar sebagai berikut (1) perasaan senang, (2) ketertarikan siswa, (3) perhatian siswa, (4) keterlibatan siswa. Responden dari kuesioner ini berjumlah 46 siswa kelas IV SD Negeri Karangroto 04 Semarang.

Dalam penelitian ini, peneliti menggunakan angket (koesioner) untuk mencari tahu tentang minat belajar matematika. Angket ini diisi sendiri oleh siswa tanpa pengaruh dari orang lain. Peneliti memberikan skor terhadap pertanyaan yang ada pada angket. Adapun pemberian skor untuk tiap-tiap jawaban adalah:

Tabel 1 Skoring Angket Minat Belajar

\begin{tabular}{ccccc}
\hline No & Pernyataan Positif & Skor & Pernyataan Negatif & Skor \\
\hline 1. & Selalu (SL) & 4 & Selalu (SL) & 1 \\
2. & Sering (SR) & 3 & Sering (SR) & 2 \\
3. & Kadang-kadang (KD) & 2 & Kadang-kadang (KD) & 3 \\
4. & Tidak Pernah (TP) & 1 & Tidak Pernah (TP) & 4 \\
\hline & & & (Sumber: Widoyoko, 2015:105)
\end{tabular}

Tabel 2. Kriteria Minat Belajar Matematika

\begin{tabular}{ccc}
\hline No. & Tingkat Pencapaian Skor & Kriteria \\
\hline 1 & $76-100 \%$ & Sangat Tinggi \\
2 & $51-75 \%$ & Cukup \\
3 & $26-50 \%$ & Kurang \\
4 & $0-25 \%$ & Sangat Rendah \\
\hline
\end{tabular}

Tabel 3. Hasil Angket Minat Belajar Matematika Siswa Kelas IV di SD Negeri Karangroto 04 Semarang

\begin{tabular}{|c|c|c|}
\hline Indikator & Kemampuan Matematika & Presentase \\
\hline \multirow[t]{3}{*}{ Perasaan senang } & Pendapat siswa tentang pembelajaran matematika & \multirow{3}{*}{$85 \%$} \\
\hline & Kesan siswa terhadap guru matematika & \\
\hline & $\begin{array}{l}\text { Perasaan siswa selama mengikuti pembelajaran } \\
\text { matematika }\end{array}$ & \\
\hline \multirow[t]{2}{*}{ Perhatian } & Perhatian saat mengikuti pembelajaran matematika & \multirow[b]{2}{*}{$80 \%$} \\
\hline & Perhatian siswa saat diskusi pelajaran matematika & \\
\hline \multirow[t]{2}{*}{ Ketertarikan } & $\begin{array}{l}\text { Rasa ingin tahu siswa saat mengikuti pembelajaran } \\
\text { matematika }\end{array}$ & \multirow[b]{2}{*}{$77 \%$} \\
\hline & Penerimaan siswa saat diberi tugas/ PR oleh guru & \\
\hline \multirow[t]{2}{*}{ Keterlibatan } & Kesadaran tentang belajar di rumah & \\
\hline & Kegiatan siswa setelah dan sebelum masuk sekolah & $73 \%$ \\
\hline
\end{tabular}


Hasil presentase dapat diperoleh dari hasil skor koesioner (angket) per anak yang dimana terdapat 26 pernyataan. Peneliti menggunakan skoring pilihan jawaban Likert. Untuk pernyataan yang bersifat positif skor jawaban adalah: $S L$ (selalu) $=4, S$ (sering) $=3, K D$ (kadang-kadang) $=2$ dan TP (tidak pernah) $=1$. Untuk pernyataan yang bersifat negatif adalah sebaliknya, yaitu: $S L=4, K D=3, S=2, T P=4$. Jumlah skor maksimal dari setiap petanyaan dapat diartikan sebagai total skor maksimal. Sedangkan jawaban anak dapat diartikan sebagai jawaban yang benar dan dianggap menjadi total skor yang diperoleh oleh siswa. Kesimpulannya yaitu total skor yang diperoleh siswa dikalikan $100 \%$ kemudian dibagi total skor maksimal sehingga dapat diperoleh presentase dari minat belajar siswa dan dapat dilihat dari rumus :

$$
\% \text { Minat Siswa }=\frac{\text { Total Skor yang diperoleh }}{\text { Total Skor Maksimal }} \times 100 \%
$$

Hasil yang diperoleh peneliti mengenai minat belajar yang telah dihitung menunjukan presentase minat belajar. Hasil tersebut kemudian akan dikategorikan untuk mengetahui tingkat minat belajar siswa pada pembelajaran matematika. Kategori tersebut yaitu: (1) Sangat Tinggi $=76-100 \%$ (2) Cukup $=51-75 \%$ (3) Kurang $=26-50 \%$ (4) Sangat Rendah $=0-25 \%$.

Berdasarkan hasil angket yang telah diisi siswa bahwa hasil jumlah total dari 26 pernyataan indikator minat belajar yang diajukan kepada 46 siswa kelas IV menunjukan total skor yang diperoleh adalah 3.793 dan total skor maksimal 4.784. Minat belajar siswa kelas IV kemudian dinyatakan kedalam presentase dengan rumus \% minat belajar sama dengan total skor yang diperoleh dikalikan 100\% kemudian dibagi skor maksimal. Hasil perhitungan menunjukan presentase minat belajar siswa yaitu $79,3 \%$ tergolong dalam kriteria minat belajar "Sangat Tinggi".

Minat menurut Sardiman (dalam Susanto, 2014: 57) suatu kondisi yang terjadi apabila seseorang melihat ciri-ciri atau arti sementara situasi yang dihubungkan dengan keinginankeinginan atau kebutuhan-kebutuhan sendiri. Oleh karena itu, apa saja yang dilihat seseorang barang tentu akan membangkitkan minatnya sejauh apa yang dilihat itu mempunyai hubungan dengan kepentingan sendiri. Hal ini menunjukan bahwa minat merupakan kecenderungan jiwa seseorang terhadap suatu objek, biasanya disertai dengan perasaan senang, karena itu merasa ada kepentingan dengan sesuatu itu.

Berdasarkan hasil koesioner (angket) yang dilakukan terkait indikator penelitian menunjukkan perasaan senang terhadap proses pembelajaran matematika dengan hasil presentase $85 \%$ dengan kriteria "Sangat Tinggi". Hal ini berarti menunjukan bahwa perasaan senang yang tinggi akan membuat minat siswa dalam pembelajaran matematika juga tinggi. Menurut Slameto, (2010:180) suatu minat dapat diekspresikan melalui suatu pernyataan yang menunjukkan bahwa siswa lebih menyukai suatu hal daripada hal lainnya, dapat pula di manifestasikan melalui partisipasi dalam suatu aktivitas.

Pada saat pembelajaran rata-rata siswa sangat antusias sekali, memperhatikan pembelajaran matematika. Guru yang menyenangkan memang sangat mempengaruhi jalannya pembelajaran dikelas. Guru dalam menjelaskan menggunakan media sederhana dan pada akhirnya siswa ingin membuatnya juga. Kegiatan pembelajaran yang dilakukan oleh siswa disertai dengan perasaan senang artinya siswa mengikuti proses pembelajaran tanpa paksaan dan atas keinginannya sendiri. Hal-hal menyenangkan yang dilakukan oleh siswa adalah mendapatkan pengalaman baru dan pembelajaran di kelas lebih bermakna.

Data yang terkumpul untuk indikator perhatian terhadap pembelajaran adalah sebesar $80 \%$. Ini berarti tingkat minat belajar siswa dilihat dari indikator belajar disertai dengan adanya perhatian tergolong "Sangat Baik". Menurut Syah, (2003: 151) seorang siswa yang menaruh 
minat besar terhadap matematika akan memusatkan perhatiannya lebih banyak daripada siswa lainnya. Kemudian karena pemusatan perhatian yang intensif terhadap materi itulah yang memungkinkan siswa tadi untuk belajar lebih giat dan akhirnya mencapai prestasi yang diinginkan.

Proses pembelajaran dilakukan pagi hari dimana siswa masih semangat dalam menerima materi pelajaran sehingga siswa sangat antusias dalam mengikuti proses pembelajaran. Ada beberapa siswa yang hanya diam saja, siswa tersebut akan menjadi perhatian guru dan segera harus diatasi agar tujuan pembelajaran tercapai. Salah satu cara yang dilakukan adalah dengan memberikan pertanyaan menantang dengan mengaitkan materi pembelajaran dengan kondisi nyata di lingkungan bermain anak yang diselingi dengan humorhumor positif sehingga dapat memancing perhatian siswa. Setelah perhatian siswa mulai terfokus pada proses pembelajaran, selanjutnya dilakukan pemberian materi secara bertahap.

Pada indikator perasaan tertarik sebanyak $77 \%$ dengan kriteria "Sangat Baik". Perasaan tertarik merupakan hal yang penting dalam menumbuhkan minat siswa. Menurut Slameto, (2010: 180) minat adalah suatu rasa lebih suka dan rasa ketertarikan pada suatu hal atau aktivitas tanpa ada yang menyuruh. Siswa yang memiliki minat pada hal tertentu berarti akan memiliki ketertarikan dan akan senang hati melakukan aktivitas yang berhubungan dengan hal tersebut.

Rasa ingin tahu siswa sangat tinggi, mereka bertanya ketika kurang paham, penerimaan ketika diberikan tugas oleh guru. Seperti contoh yang dikemukakan oleh Sembiring dan Mukhtar (2013:223) bahwa siswa yang memiliki minat terhadap ilmu/pelajaran matematika akan merasa tertarik dan senang untuk melakukan segala kegiatan yang berhubungan dengan matematika. Minat terhadap suatu mata pelajaran tertentu memberikan semangat kepada siswa untuk mempelajarinya.

Indikator keterlibatan dengan presentase sebanyak 73\% dengan kriteria "Cukup Baik". Ketelibatan siswa akan memudahkan siswa dalam menerima materi yang diajarkan seperti kesadaran tentang belajar ketika dirumah. Menurut Slameto (2010: 180) apabila siswa menyadari bahwa belajar merupakan suatu alat untuk mencapai beberapa tujuan yang dianggapnya penting dan bila siswa melihat bahwa hasil dari pengalaman belajarnya akan membawa kemajuan pada dirinya, kemungkinan besar ia akan berminat (dan memotivasi) untuk mempelajarinya.

Hasil secara keseluruhan mengenai minat belajar pada mata pelajaran matematika dari 4 indikator yang telah diujikan menunjukan hasil minat belajar siswa kelas IV pada mata pelajaran matematika sebesar $79,3 \%$ tergolong kriteria minat belajar "Sangat Tinggi". Kriteria minat belajar "Sangat Tinggi" yaitu 76-100\%, kriteria minat belajar dapat dilihat pada tabel 2.

Berdasarkan hasil observasi yang dilakukan pada kelas IV SD Negeri Karangroto 04 Semarang, minat belajar siswa pada mata pelajaran matematika bisa dikategorikan sangat tinggi. Hal tersebut terlihat ketika proses pembelajaran dikelas, siswa sangat antusias dalam mengikuti pembelajaran matematika. Guru yang menyenangkan juga membuat siswa lebih bersemangat dalam belajar. Guru menggunakan media pembelajaran sederhana sehingga memudahkan siswa dalam memahami materi. Guru menerapkan pembelajaran kooperatif learning (bekerja sama atau belajar kelompok) dan juga belajar dengan teman (tutor sebaya) sehingga pembelajaran matematika tidak membosankan.

Pembelajaran matematika dilaksanakan pada pagi hari sehingga siswa fresh dan siap dalam mengikuti pembelajaran matematika. Perhatian siswa saat mengikuti pembelajaran matematika sangat besar. Siswa aktif dalam berdiskusi dan bertanya. Ada beberapa siswa yang hanya diam saja, guru selalu memberikan perhatian dan memberi bimbingan pada siswa secara bergantian. Di akhir pembelajaran tak lupa guru memberikan evaluasi pembelajaran sehingga guru mengetahui kemampuan siswa dan materi mana yang sekiranya sulit bagi siswa.

Berdasarkan wawancara dengan guru kelas IV menjelaskan bahwa dalam proses pembelajaran matematika di kelas, rata-rata siswa antusias dalam mengikutinya. Guru dalam menjelaskan materi matematika juga bertahap agar siswa lebih paham. Yang semula siswa 
kurang berminat dengan mata pelajaran matematika jika di jelaskan secara bertahap mereka akan lebih paham dan akan menjadi senang terhadap matematika.

Dalam pembelajaran matematika, tentunya ada yang memperhatikan ataupun tidak. Tugas guru di sini adalah membuat kelas menjadi aktif dan seringkali guru melakukan diskusi kelas (kooperatif learning), belajar bersama teman (tutor sebaya) agar belajar siswa lebih bermakna. Guru juga menggunakan media pembelajaran seperti gambar-gambar yang menyesuaikan dengan materi yang dibahas.

Setelah guru menerangkan materi, guru mempersilahkan siswa untuk mencatat dan bertanya. Ada beberapa siswa yang aktif dalam bertanya seperti Nayla Kumalasari, Alfa, Intan, David, Dian, Shellita, Sela, Sindy, Salsabila dan banyak siswa yang hanya diam. Untuk mengecek pemahaman mereka semua, guru memberikan evaluasi kepada siswa agar bisa diketahui materi mana yang sekiranya mengalami kesulitan.

Di akhir pembelajaran, guru memberikan tugas di rumah (PR) untuk siswa dengan tujuan siswa akan lebih paham dengan materi, dirumah mereka juga belajar dan di suruh mempelajari materi berikutnya. Pastinya ada yang mengeluhkan kenapa matematika selalu di berikan pekerjaan rumah, tapi banyak dari siswa yang bisa menerima karena mereka menyadari agar mereka bisa lebih memahami materi matematika. Siswa dalam pembelajaran tidak bisa menghindar dari pembelajaran matematika karena di dalam kehidupan banyak bisa diterapkan ilmu matematika.

\section{Simpulan dan Saran}

Berdasarkan hasil penelitian dan analisis data dapat disimpulkan bahwa minat belajar siswa kelas IV pada mata pelajaran matematika di SD Negeri Karangroto 04 Semarang menunjukan hasil sebesar 79,3\% tergolong kriteria minat belajar "Sangat Tinggi".

Berdasarkan hasil penelitian, saran yang dapat diajukan adalah (1) Bagi guru diharapkan menggunakan media, model dan metode pembelajaran yang lebih bervariasi supaya siswa semakin cepat tanggap, cepat mengerti dan tidak mudah bosan dalam pembelajaran sehingga minat belajar matematika tetap tinggi dan pembelajaran semakin berjalan dengan baik. (2) Bagi siswa diharapkan menjaga dan meningkatkan minat belajarnya terutama dalam mata pelajaran matematika.

\section{Daftar Pustaka}

Abdurrahman, Mulyono. 2012. Anak Berkesulitan Belajar Teori Diagnosis dan Remediasinya. Jakarta: PT. Rineka Cipta.

Ahmadi, Abu. 2009. Psikologi Sosial. Jakarta: PT. Rineka Cipta.

Anam, Khoirul. 2015. "Pengaruh Media Pembelajaran Terhadap Minat Belajar Siswa Pada Mata Pelajaran PAI di SMP Bani Muqiman Bangkalan".

Arnie, Fajar. 2009. Portofolio Dalam Pembelajaran Ilmu Pengetahuan Sosial. Bandung: Remaja Rosdakarya.

Arikunto, Suharsimi. 2013. Prosedur Penelitian Suatu Pendekatan Praktik. Jakarta: Rineka Cipta.

Dalyono, M. 2005. Psikologi Pendidikan. Jakarta: Rineka Cipta.

Danarjati, Dwi Prasetia, dkk. 2014. Psikologi Pendidikan. Yogyakarta: Graha Ilmu.

Djaali. 2009. Psikologi Pendidikan. Jakarta: Bumi Aksara. 
Djiwandono, Sri Esti Wuryani. 2009. Psikologi Pendidikan. Jakarta: PT Grasindo.

Gunawan, Imam. 2015. Metode Penelitian Kualitatif Teori dan Praktik. Jakarta: PT Bumi Aksara.

Islamuddin, Haryu. 2012. Psikologi Pendidikan. Yogyakarta: Pustaka Pelajar.

Nurhabib, Hilal. 2015. Analisis Minat Belajar Siswa Kelas IV dalam Proses Pembelajaran Tematik di SD Negeri 3 Brebes.

Prahara, Haris. 2017. "Pada 2020, Tak ada Lagi Pelajaran Matematika di Negeri Ini”. (Online). Tersedia: https://edukasi.kompas.com/read/2017/09/19/13445611/pada-2020-tak-adalagi-pelajaran-matematika-di-negara-ini. Diakses pada tanggal 2 Juni 2018 Pukul 08:53.

Jahja, Yudrik. 2013. Psikologi Perkembangan. Jakarta: Kencana Prenadamedia Group.

K, Sukada, dkk. 2013. "Kontribusi Minat Belajar, Motivasi Berprestasi Dan Kecerdasan Logis Matematika Terhadap Hasil Belajar Matematika Siswa".

Mahmud. 2012. Psikologi Pendidikan. Bandung: CV Pustaka Setia.

Moleong, Lexi J. 2011. Metodologi Penelitian Kualitatif. Bandung: PT. Remaja Rosdakarya.

Moleong, Lexi J. 2014. Metodologi Penelitian Kualitatif. Bandung: PT. Remaja Rosdakarya.

Rusman. 2013. Belajar dan Pembelajaran Berbasis Komputer. Bandung: Alfabbeta.

Sembiring, Rosali dan Mukhtar. 2013. Strategi Pembelajaran dan Minat Belajar terhadap Hasil Belajar Matematika. Jurnal Teknologi Pendidikan.

Susanto, Ahmad. 2014. Teori Belajar dan Pembelajaran di Sekolah Dasar. Jakarta: Kencana Prenadamedia Group.

Slameto. 2013. Belajar dan Faktor-faktor yang Mempengaruhinya Jakarta: Rineka Cipta.

Sugiyono. 2017. Metode Penelitian Kuantitatif kualitatif Dan R\&D. Bandung. CV. Alfabeta.

Sujarwo. 2001. Metodologi Penelitian Sosial. Bandar Lampung: CV.Mandar Maju.

Sukmadinata, Nana Syaodih. 2007. Landasan Psikologi Proses Pendidikan. Bandung: PT Remaja Rosdakarya.

Syah, Muhibbin. 2006. Psikologi Belajar. Jakarta: PT RajaGrafindo Persada.

Undang-undang Nomor 20 Tahun 2003 tentang Sistem Pendidikan Nasional

Widoyoko, Eko Putro. 2015. Teknik Penyusunan Instrumen Penelitian. Yogyakarta: Pustaka Pelajar.

Zusnani, Ida. 2013. Pendidikan Kepribadian Siswa SD-SMA. Jakarta Selatan: Tugu Publisher 